\title{
Mitotic catastrophe induced in HeLa cells by photodynamic treatment with $\mathrm{Zn}(\mathrm{II})$-phthalocyanine
}

\author{
SANTIAGO RELLO-VARONA ${ }^{1}$, JUAN CARLOS STOCKERT ${ }^{1,2}$, MAGDALENA CAÑETE ${ }^{1}$, \\ PILAR ACEDO ${ }^{1}$ and ÁNGELES VILLANUEVA ${ }^{1}$ \\ ${ }^{1}$ Departamento de Biología, Facultad de Ciencias, Universidad Autónoma de Madrid, C/ Darwin 2, \\ Citología A-115, E-28049 Madrid; ${ }^{2}$ Centro de Investigaciones Biológicas, Consejo Superior \\ de Investigaciones Científicas, C/ Ramiro de Maeztu 9, E-28040 Madrid, Spain
}

Received January 15, 2008; Accepted February 25, 2008

\begin{abstract}
Photodynamic therapy (PDT) is a tool against neoplastic and non-neoplastic diseases. PDT is capable to induce different cell death mechanisms in vitro, triggered in a dose-dependent manner. Relationships between PDT and apoptosis or necrosis induction are well-known, but other cell death mechanisms triggered after PDT are less understood. Here we present our results in p53-deficient human cervix carcinoma HeLa cells subjected to sublethal PDT treatments (mortality about $40 \%$ ) using $\mathrm{Zn}(\mathrm{II})$-phthalocyanine ( $\mathrm{ZnPc}$ ) incorporated into liposomes. We obtained a rapid metaphase blockage of cells that also showed clearly altered configurations of the mitotic spindle. Cell cycle arrest was followed by aneuploidisation and cell death with apoptotic morphology. Apoptosis was also confirmed by occurrence of PARP cleavage and Bax translocation to mitochondria. These features are components of the cell death mechanism known as mitotic catastrophe and represent, to our knowledge, the first description of this cell death modality after PDT with ZnPc.
\end{abstract}

\section{Introduction}

Zinc(II)-phthalocyanine ( $\mathrm{ZnPc})$ is one of the so-called second generation agents for photodynamic therapy (PDT), which is a useful treatment of neoplastic and non-neoplastic diseases (1). It is based on the appropriate combination of oxygen, light and a photosensitiser compound (PS), which becomes excited and mediates the production of cytotoxic reactive oxygen species (ROS) (1).

Correspondence to: Dr Santiago Rello-Varona, Departamento de Biología, Facultad de Ciencias, Universidad Autónoma de Madrid, C/ Darwin 2, Citología A-115, E-28049 Madrid, Spain

E-mail: santiago.rello@uam.es

Key words: mitotic catastrophe, photodynamic therapy, zinc phthalocyanine, HeLa cells, cell death, apoptosis
Approved PDT protocols are mainly related with first generation photosensitisers (i.e. Photofrin ${ }^{\circledR}$ ), while basic research is most centred in second generation PSs with improved photophysical characteristics (2). Among them, phthalocyanines are highlighted by their increased absorbance coefficient at wavelengths with optimal tissue penetration (in the $630-800 \mathrm{~nm}$ spectral region). $\mathrm{ZnPc}$ has particular interest on account of its long-lived triplet state and good capacity for localisation in tumours (2).

However, in spite of their interesting properties, the extreme hydrophobicity of phthalocyanines makes necessary the use of specific carriers for delivery into biological systems (2). At present, several $\mathrm{ZnPc}$ formulations are used for experimental purposes, examples being nanoparticles (3), dispersions (4), micelles (5) and different types of liposomes (6).

Mitotic catastrophe is a specific cell death process intimately related with defective mitosis behaviour causing cell cycle arrest, evident alterations in the spindle and chromosome disposition, aneuploidy, and finally cell death $(7,8)$. Mitotic catastrophe and subsequent aneuploidy are also linked with genomic instability, tumour progression, development of drug resistance, and aging and senescence $(9,10)$. Those processes indicate several alterations in checkpoint regulation, principally related with p53 abrogation or dysfunction $(9,11,12)$, as the signalling cascades regulated by 553 maintain the genome integrity and trigger cell death when a severe damage occurs (13).

Several chemicals cause cell death preceded by different events of the so-called mitotic catastrophe program, especially spindle aberrations that lead to metaphase arrest $(14,15)$. They are, mainly, chemotherapeutic agents targeted against the microtubule system $(16,17)$. Paclitaxel $\left(\right.$ Taxol $\left.^{\circledR}\right)$ is the most known microtubule interfering agents but, other compounds are also used in different trial phases (i.e. Vinca alkaloids, colchicine derivatives, etc.) (16).

The Bcl-2 family proteins are targets of p53 activity and there is evidence connecting them with different cell death processes compressing mitotic catastrophe $(12,18)$. Bcl-2 family proteins regulate the integrity of the mitochondrial membranes as a result of a complex hierarchical behaviour (19), releasing cytochrome $\mathrm{c}$ and inducing apoptosis with the 
activation of caspases (20). The role of Bcl-2 family proteins in PDT has attracted great interest, as mitochondria are now considered the principal target of this therapeutical approach $(21,22)$.

$\mathrm{ZnPc}$ photosensitisation produces ROS that are responsible for cell damage (4). As ROS have a very small action radius, photodamage was traditionally considered to be restricted to subcellular areas where the PS is accumulated $(1,23)$.

Previously, we have described dramatic cytoskeletal alterations (mainly compressing microtubules, MTs) after ZnPc-PDT treatments of p53-deficient HeLa cells (24). These alterations included spindle aberrations that lead to metaphase arrest, but no further experiments were made at that time. The aim of the present work is to determine if ZnPc-PDT can inactivate HeLa cells by means of a mitotic catastrophe response.

\section{Materials and methods}

The p53-deficient HeLa cell line (25) was grown in Dulbecco's modified Eagle's medium (DMEM) with $50 \mathrm{U} / \mathrm{ml}$ penicillin, $50 \mu \mathrm{g} / \mathrm{ml}$ streptomycin and supplemented with fetal bovine serum (FBS) at a final concentration of $10 \%$ (whole medium). All the media, sera and antibiotics were provided by Gibco (Paisley, UK). Cell cultures were performed in a $5 \% \mathrm{CO}_{2}$ atmosphere at $37^{\circ} \mathrm{C}$.

Depending on the experiment, cells were seeded in $25 \mathrm{~cm}^{2}$ flasks $(90,000$ cells $)$ or in $35 \mathrm{~mm}$ Petri dishes $(20,000$ cells) with or without $22 \mathrm{~mm}$ square coverslip. All sterile plastics were from Corning Inc. (Corning, USA). Cells were grown for $72 \mathrm{~h}$ and treated when cultures were in exponential growth.

ZnPc supply and treatment conditions. Zinc(II) phthalocyanine was acquired from Sigma-Aldrich (St. Louis, USA). A stock $0.5 \mathrm{mg} / \mathrm{ml}$ solution was prepared in pyridine (Panreac Química, Montcada i Reixac, Spain) and stored at $4^{\circ} \mathrm{C}$ until use. ZnPc was incorporated into dipalmitoyl-phosphatidyl-choline (DPPC) liposomes (Sigma) according to the injection procedure of Ginevra and co-workers (26). Liposome solution was sterilized by filtration with a $0.22 \mu \mathrm{m}$ diameter filter (Millipore Corp., Bedford, USA). The concentration of the ZnPc-DPPC stock solution was measured using a Shimadzu UV-1601 spectrophotometer (Kyoto, Japan); for working, $\mathrm{ZnPc}$ was diluted in phosphate buffered saline (PBS) or in $1 \%$ FBS medium to desired concentrations, within the first $48 \mathrm{~h}$ after stock preparation.

Cellular uptake of $\mathrm{ZnPc}$ was measured, using different incubation conditions, with a Perkin-Elmer 650-10S Fluorescence Spectrophotometer (Waltham, USA), after $2 \%$ sodium dodecyl sulphate (SDS) lysis of the cells. Lysate fractions were preserved for protein quantification by the BCA assay (Pierce, Rockford, USA). ZnPc localisation within cells was analysed after 24-h incubation with $2.5 \mu \mathrm{M}$ ZnPc-DPPC solution in DMEM. Microphotographs were taken with an Olympus BX61 epifluorescence microscope equipped with an Olympus DP50 digital camera under ultraviolet (UV, $365 \mathrm{~nm}$ ) excitation.

For PDT treatments, cells were incubated with $10^{-7} \mathrm{M}$ ZnPc-DPPC solution in PBS for one hour, washed three times with fresh PBS and maintained in whole medium during irradiation and post-treatment time. Red light irradiation for 15 min was performed using a LED source $(\lambda=640 \pm 20 \mathrm{~nm})$ with a mean intensity of $4 \mathrm{~mW} / \mathrm{cm}^{2}$, measured with a M8 Spectrum Power Energymeter.

Cell survival. Thiazolyl blue (MTT, Sigma) was used for the assessment of cell survival. A stock solution $(1 \mathrm{mg} / \mathrm{ml})$ in PBS was prepared immediately prior to use. Solution (100 $\mu \mathrm{l})$ were added to each culture dish (containing $2 \mathrm{ml}$ of whole medium; final MTT concentration: $47.6 \mu \mathrm{g} / \mathrm{ml}$ ). Cells were incubated for $3 \mathrm{~h}$; formazan precipitates were dissolved in $1.5 \mathrm{ml} \mathrm{DMSO}$ and the absorbance was measured at $540 \mathrm{~nm}$ in a Tecan Spectra Fluor spectrophotometer. Cell survival was expressed as the percentage of absorption of treated cells in comparison with that of control cells. The results presented were the mean value and standard deviation from at least six different experiments.

MTT procedure results were confirmed using also the trypan blue (TB, Sigma) exclusion test. Briefly, treated and untreated cells were trypsinised (harvesting also the detached ones) and mixed $50 \%$ with $300 \mu 1$ of a $0.2 \%$ TB solution in PBS. Cell counting of death (blue) or alive (white and bright cells) was performed using a Neubabuer haemocytometer chamber (Marienfeld GmbH, Lauda-Königshofen, Germany).

Microscopical analysis. The effects of PDT treatments were studied mainly by microscopical observations. Cells were routinely observed at different time intervals using an inverted microscope. Further analysis was performed by $\alpha$-tubulin FITC-fluorescence immunostaining on cold-methanol fixed cells (permeabilised with $0.5 \%$ Triton $\mathrm{X}-100$ in PBS); nuclei were counterstained using $0.5 \mathrm{mg} / \mathrm{ml}$ Hoechst-33258 (H-33258, Sigma) solution in distilled water. Centromeres were immunolabelled using purified human anti-centromere proteins (Antibodies Inc., Davis, CA, USA) as primary antibody and goat anti-human IgG (Fc specific) TRITC-labelled antibody. Bcl-2 family protein Bax was immunolabelled with mouse anti-Bax (2D2) primary antibody (Santa Cruz Biotech., Santa Cruz, USA). For comparison purposes, immunostaining of the Golgi apparatus and mitochondria was performed using antibodies against the proteins golgin 58 and cytochrome c (respectively) as targets and, in these cases, cells were fixed in $3.5 \%$ paraformaldehyde (BDH, Poole, UK) for $20 \mathrm{~min}$ at $4^{\circ} \mathrm{C}$. All fixatives, stains, and antibodies were from Sigma.

Microscopical analysis was also used for assessing cell death. Apoptotic cells were identified using morphological criteria (mainly chromatin condensation and packing into apoptotic bodies) (27). Cell counting was performed from samples fixed in paraformaldehyde and stained with $0.5 \mathrm{mg} / \mathrm{ml}$ H-33258.

Observations were made with an Olympus BX61 microscope/Olympus DP50 digital camera; all photographs were taken using Photoshop CS software (Adobe Systems, San Jose, USA).

Flow cytometry analysis. Analysis of the cell cycle was performed by measurement of propidium iodide (PI) labelling of DNA cell content. Flasks were trypsinised (harvesting also the detached cells) and centrifuged at $1200 \mathrm{rpm}$ (rotor radius: 
Table I. Cellular uptake of ZnPc incorporated into DPPC liposomes. ${ }^{\mathrm{a}}$

Incubation

$\begin{array}{lr}10^{-7} \mathrm{M}-1 \mathrm{~h} & 4.8 \pm 1.6 \\ 10^{-7} \mathrm{M}-24 \mathrm{~h} & 17.1 \pm 0.5 \\ 2.5 \mu \mathrm{M}-1 \mathrm{~h} & 35.7 \pm 7.6 \\ 2.5 \mu \mathrm{M}-24 \mathrm{~h} & 233.7 \pm 47.0\end{array}$

${ }^{a}$ The results are presented as ng of $\mathrm{ZnPc} / \mathrm{mg}$ of total proteins. Data correspond to mean values \pm standard deviation (SD) from six different experiments.

$7 \mathrm{~cm}$ ) for $5 \mathrm{~min}$ for pelleting prior to fixing with cold $70 \%$ ethanol solution (15 min, on ice). After centrifugation, the pellet was resuspended in $1 \mathrm{ml}$ of fresh PBS with $50 \mu \mathrm{l}$ of a $100 \mu \mathrm{g} / \mathrm{ml}$ solution of RNase and incubated for half an hour at $37^{\circ} \mathrm{C}$. Immediately prior to measurement, DNA was stained by adding $25 \mu 1$ of $1 \mathrm{mg} / \mathrm{ml}$ PI solution. All reactives were from Sigma. Measurements were performed with a Coulter Epics XL-MCL flow cytometer with an argon laser line at $488 \mathrm{~nm}$ and complemented with the appropriate filters.

Western blot analysis. For protein analysis by Western blot techniques, samples from ZnPc-PDT treatments were obtained. Whole protein content was extracted by lysis using RIPA buffer $[50 \mathrm{ml}$ of distilled water with $50 \mathrm{mM}$ Tris- $\mathrm{HCl}$ at $\mathrm{pH} 8.0 ; 150 \mathrm{mM} \mathrm{NaCl} ; 1 \%$ (v/v) Igepal CA630 (all from Sigma) and $0.1 \%(\mathrm{v} / \mathrm{v})$ SDS; complemented with a tablet of complete EDTA-free protease inhibitors (Roche)].

Protein concentration was determined using a BCA assay kit and samples were loaded and separated on 10\% SDSPAGE and transferred to nitrocellulose membranes using Mini-Protean 3 equipment, with the appropriate reactives, according to manufacturer instructions (Bio-Rad, Hercules, USA).

The chemiluminescent detection of proteins was performed using mouse monoclonal anti- $\beta$-actin (clone AC-15), as control, and mouse monoclonal anti-PARP (clone C-2-10). The secondary antibody employed was sheep ECL anti-mouse horseradish peroxidase conjugate (Amersham Biosciences, Bucks, UK). Bands were revealed in Curix CP-G Plus paper (AGFA, Barcelona, Spain) with Western Blotting Luminol Reagent (Santa Cruz).

\section{Results}

Uptake and localisation of ZnPc in HeLa cells. The incorporation of $\mathrm{ZnPc}$ was studied by fluorimetric analysis of lysates from cells previously incubated with different PS concentrations for short and long time intervals. Results are summarized in Table I. The amount of $\mathrm{ZnPc}$ in cells is increased in function of the concentration and the time interval employed. In our experimental conditions, using a short incubation period with a very low concentration, the presence of $\mathrm{ZnPc}$ is enough to be detected (4.8 $\mathrm{ng}$ of $\mathrm{ZnPc} / \mathrm{mg}$ of protein).

Once the presence of the PS was confirmed, we studied its precise accumulation site inside the cells, using the red fluorescence of $\mathrm{ZnPc}$ under ultraviolet excitation. Under our PDT treatment conditions the amount of intracellular $\mathrm{ZnPc}$ was too low to allow imaging; but we succeed using the largest uptake conditions assayed (2.5 $\mu \mathrm{M} \mathrm{ZnPc}$ for $24 \mathrm{~h}, 233.7 \mathrm{ng}$ $\mathrm{ZnPc} / \mathrm{mg}$ protein). In Fig. 1 we show the localisation of $\mathrm{ZnPc}$ in HeLa cells. The red signal of the PS is constrained to a single area near the nucleus. No co-localisation between the red $\mathrm{ZnPc}$ signal and the blue auto-fluorescence of the mitochondria was observed (Fig. 1B and C). The ZnPc signal diverged from the typical morphology of the mitochondrial network (Fig. 1E by cytochrome c immuno-staining) but is quite similar to that of the Golgi apparatus (Fig. 1D after golgin 58 immunolabelling). In summary, liposomally-driven $\mathrm{ZnPc}$ penetrated into HeLa cells and accumulated in the Golgi apparatus.

Cell cycle arrest. The first effect caused by our treatment conditions $\left(10^{-7} \mathrm{M} \mathrm{ZnPc}\right.$ for $1 \mathrm{~h}, 15 \mathrm{~min}$ light exposure) is evident $6 \mathrm{~h}$ after the irradiation $(\Delta \mathrm{T}=6 \mathrm{~h}$ ). Cells start to become blocked at metaphase as visualised under fluorescence microscopy with tubulin immunolabelling (Fig. 2A and B, right panels).

This metaphase blockage was quantified using PI labelling of DNA and flow cytometry (Fig. 2A and B, left panels); the $\mathrm{G}_{2} / \mathrm{M}$ peak increases from $9.7 \%$ (in the control culture) to $17.8 \%$, and a new area of polyploid cells reaches $11.7 \%$ of the total cell population. In general, the PI profile suffered a movement towards the right, indicating processes of aneuploidisation.

Alterations in metaphase morphology. A more detailed analysis of the metaphase-blocked cells revealed several abnormalities both in microtubule and chromosome arrangements (Fig. 3). A great amount of mitotic cells showed alterations of the mitotic spindle, but the most frequent modifications were the presence of extra poles (Fig. 3B-D). The commonest mitotic morphology had three poles but cells with more poles were also seen. The disruption of the normal equilibrium between the forces on the spindle by these extra poles, caused abnormalities in the chromosome disposition in the metaphase plate with dispersed and delayed chromosomes (Fig. 3B and C). The total absence of a regular congregation of chromosomes into a plate resulted in a 'cloud disposition' of chromosomes (Fig. 3D). By means of centromere immunolabelling, we also observed that no chromosomal fragmentation occurred: dispersed and delayed chromosomes did not represent acentric fragments and, even in metaphases with a 'cloud disposition', regular centromeric signals were clearly visible (Fig. 3D).

Aneuploidy. Metaphase blockage is closely linked to aneuploidy. In our experimental conditions, a significant increase of cells placed in the 'polyploid' sector of the flow cytometry profile was shown (reaching 11.7\% $6 \mathrm{~h}$ after light exposure, see Fig. 2B). Aneuploid cells were microscopically recognisable due to size increase and typical morphological abnormalities. In our experimental conditions, aneuploid cells 

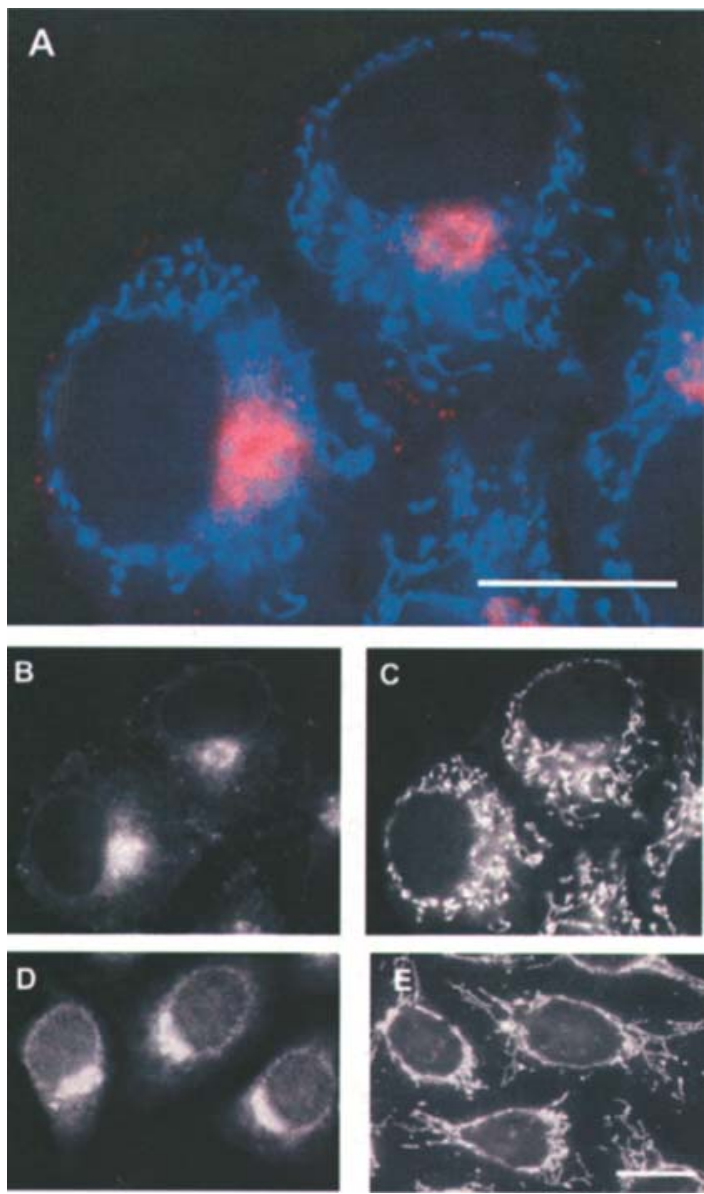

Figure 1. Subcellular localisation of ZnPc in HeLa cells. Scale bar, $10 \mu \mathrm{m}$. A, Photograph obtained by fluorescence microscopy under UV excitation showing the red signal of $\mathrm{ZnPc}$ in a Golgi apparatus-like area near the nucleus. B-E, Isolating the red and blue channels of the above photograph clearly emphasises that the red signal of $\mathrm{ZnPc}(\mathrm{B})$ does not co-localise with the blue signal of mitochondria $(\mathrm{C})$. The site of $\mathrm{ZnPc}$ accumulation strongly resembles that of the Golgi apparatus (D, golgin 58 immunostaining), and is very different to the mitochondria (E, cytochrome $\mathrm{c}$ immunostaining).

showed a round-like outline (rather than polygonal), with multiple microtubule organizing centres and chromosomes disposed within two or three nuclei of similar size (Fig. 3E).

Cell death. The metaphase blockage was still recognizable $24 \mathrm{~h}$ after irradiation, but the total amount of cells stopped at mitosis decreased from $\Delta \mathrm{T}=6 \mathrm{~h}$. At $\Delta \mathrm{T}=24 \mathrm{~h}$ it was possible to observe for the first time the presence of an important number of detached cells, which increased with time.

We performed two different assays to determine cell death after PDT treatment: MTT and trypan blue assays. Both results (summarized in Table II) were consistent and showed the cell death progression after PDT treatments.

Cell viability decreased with time until levels at about $60 \%$ at $\Delta \mathrm{T}=72 \mathrm{~h}$ after treatment. As shown in Fig. 4 after H-33258 DNA staining, cells trypsinised from the flasks (saving also the detached ones) could be divided in two groups (Fig. 4A). One group consisted of living cells with apparently normal nuclei, the other included death cells showing chromatin condensation, marginalization and fragmentation (see also Fig. 4B).
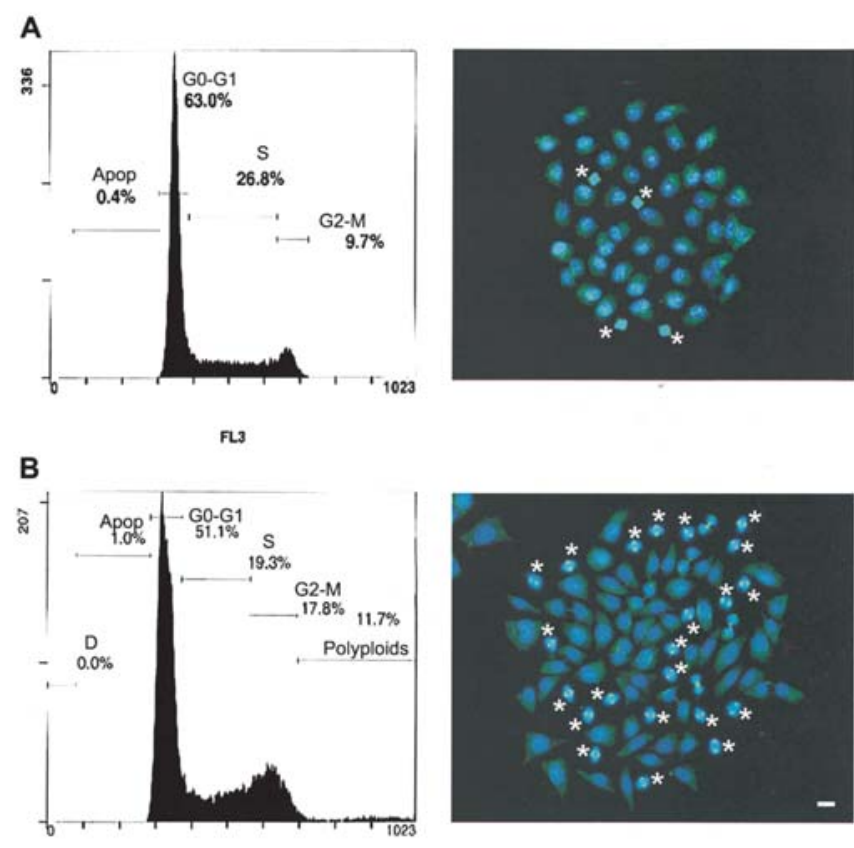

Fl3

Figure 2. ZnPc-PDT treatment of HeLa cells rapidly causes dramatic alterations of cell cycle. Scale bar, $10 \mu \mathrm{m}$. A, left, flow cytometry of DNA content (measured by PI) of control cells; right, a colony of control cells visualized by tubulin immunolabelling (green) and H-33258 staining of nuclei (blue). B, left, PI profile of HeLa cells $6 \mathrm{~h}$ after $10^{-7} \mathrm{M}$ ZnPc-PDT (1-h incubation, $15 \mathrm{~min}$ red light irradiation), $\mathrm{G}_{2} / \mathrm{M}$ and polyploid areas are clearly increased; right, a HeLa colony $6 \mathrm{~h}$ after this PDT treatment showing numerous cells blocked at metaphase (marked with asterisks).

These morphological features and detachment from substrate are typical of cell death by apoptosis. Using these microscopical criteria for direct cell counting in samples stained only with H-33258 the amount of apoptotic cells $48 \mathrm{~h}$ after light exposure was $30.50 \pm 2.02 \%$. At $72 \mathrm{~h}$ after treatment the apoptotic counting reached $35.47 \pm 0.86 \%$.

The involvement of apoptosis as the main cell death mechanism was also confirmed using the cleavage of PARP protein as visualised by western blotting (Fig. 4C). Cleaved PARP was visible at the same time when the first detached cells occurred ( $24 \mathrm{~h}$ after irradiation) and continued 48 and $72 \mathrm{~h}$ after light exposure. Using purified samples of detached cells at $72 \mathrm{~h}$, the cleavage of PARP became more evident (Fig. 4C), showing that this population was formed exclusively by apoptotic cells. The behaviour of the proapoptotic Bcl-2 family protein Bax confirmed this apoptotic mechanism. By immunostaining and microscope imaging of Bax we observed that death cells showed an increased signal intensity, which appeared concentrated in structures corresponding to mitochondria instead of having a diffuse cytosolic pattern typical of living HeLa cells (Fig. 4D, left panel).

It is important to remark that, several hours after light exposure, it was still possible to find mitotic cells with diffuse Bax signal, clearly distinguishable from apoptotic ones showing mitochondrial Bax localisation (Fig. 4D, right panel). The total amount of mitosis is, however, reduced (mitotic index $=3.11 \pm 0.97 \%$ at $\Delta \mathrm{T}=72 \mathrm{~h}$ ), and most mitotic cells 

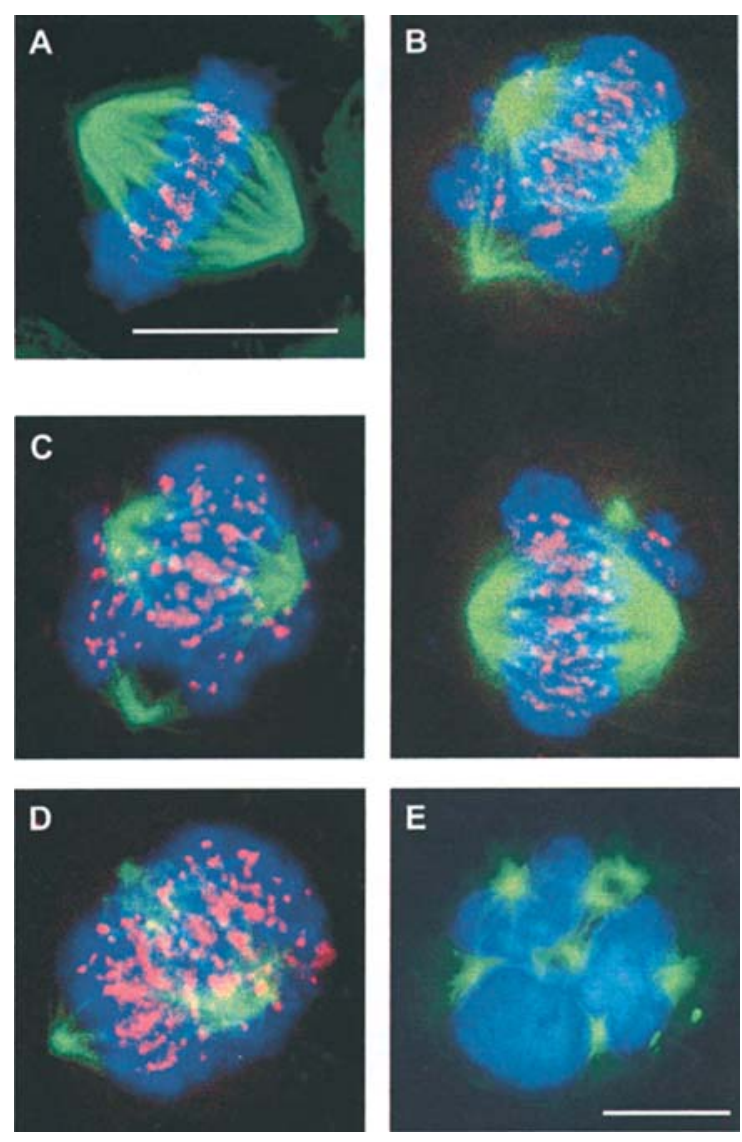

Figure 3. Details of the abnormalities of mitotic HeLa cells $6 \mathrm{~h}$ after ZnPc-PDT. Confocal microscopy: DNA in blue, $\alpha$-tubulin in green, centromeres in red. Scale bars $10 \mu \mathrm{m}$. A, Control metaphase. B, Two metaphases showing the emergence of a third spindle pole disturbing the convergence of some chromosomes. C, Tripolar metaphase showing a greater dispersion of chromosomes. D, Abnormal metaphase showing irregularly dispersed chromosomes; metaphase abnormalities (B-D) do not correlate with chromosome fragmentation and dispersed or delayed chromosomes always show centromere signal. E, HeLa aneuploid cell from a culture $24 \mathrm{~h}$ after light exposure, showing gigantism, three size-equivalent nuclei and multiplication of microtubule organizing centres.

Table II. Cell survival after $10^{-7} \mathrm{M}$ ZnPc-PDT treatment, measured by MTT and Trypan blue assays. ${ }^{\mathrm{a}}$

\begin{tabular}{lcc}
\hline & MTT & Trypan blue \\
\hline Control cells & $100 \pm 2.6$ & $98.7 \pm 1.0$ \\
$\Delta \mathrm{T}=24 \mathrm{~h}$ & $86.5 \pm 4.3$ & $86.4 \pm 4.3$ \\
$\Delta \mathrm{T}=48 \mathrm{~h}$ & $70.1 \pm 0.7$ & $74.3 \pm 4.8$ \\
$\Delta \mathrm{T}=72 \mathrm{~h}$ & $60.7 \pm 9.0$ & $62.0 \pm 1.3$ \\
\hline
\end{tabular}

${ }^{a}$ The results are presented as the surviving fraction in percentage. Data correspond to mean values \pm standard deviation (SD) from six different experiments. $\Delta \mathrm{T}$, elapsed time after PDT treatment.

showed aberrant chromosome configurations (mainly delayed chromosomes).

Taking together, all the above features (metaphase blockage, spindle's abnormalities, appearance of aneuploid and
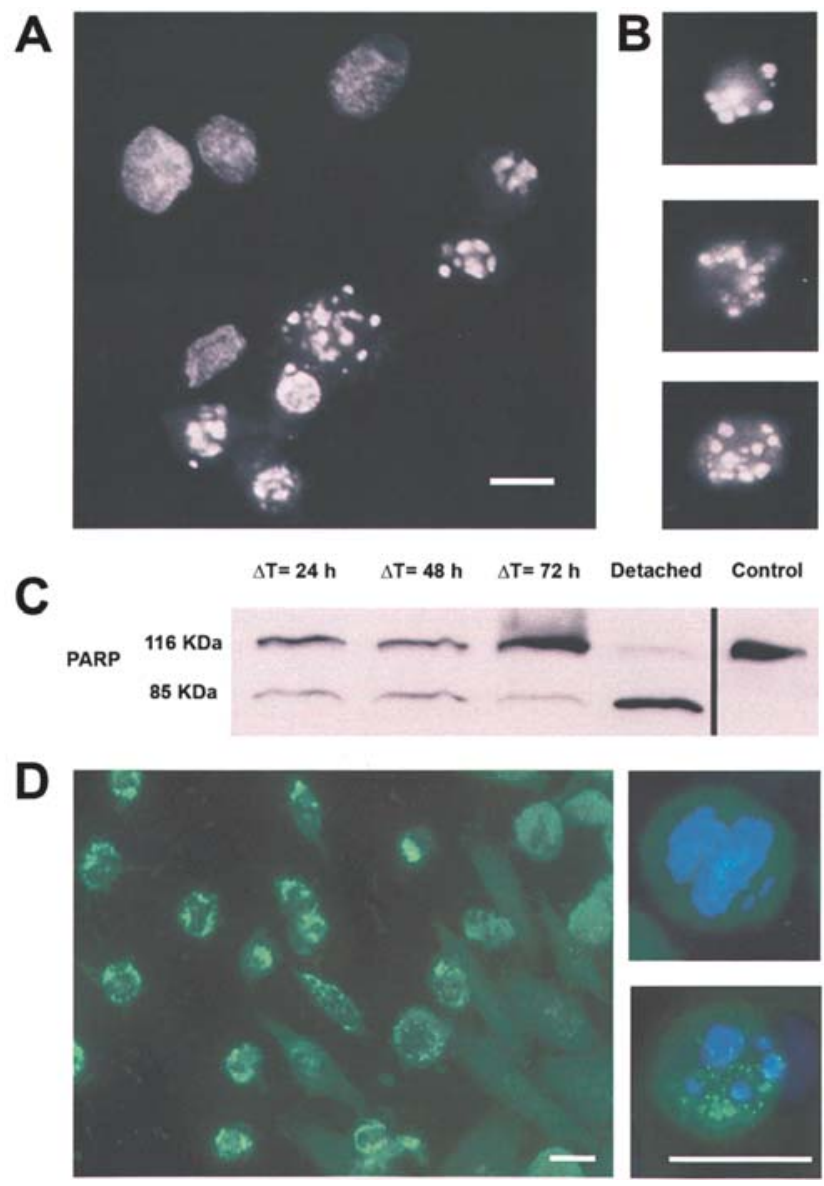

Figure 4. ZnPc-PDT induced cell death. Scale bar, $10 \mu \mathrm{m}$. A, Cells trypsinised from flasks $72 \mathrm{~h}$ after light exposure and visualised by H-33258 staining. There are clearly two groups: living cells with normal round nuclei and death ones with pycnotic and condensed nuclei. B, Details of some death cells showing chromatin condensation and marginalization (typical morphology of apoptosis). C, Cleavage of PARP revealed by Western blotting shows both the coexistence of living and apoptotic cells from $24 \mathrm{~h}$ after irradiation and the apoptotic nature of the detached cells (collected at $\Delta \mathrm{T}=72 \mathrm{~h}$ ). D, Dying cells also show Bax translocation to mitochondria $48 \mathrm{~h}$ after light irradiation (left panel). At this time, mitotic cells (despite abnormal configuration) are still living and show a diffuse Bax pattern (right-upper panel); in contrast, apoptotic cells show the Bax signal concentrated in several discrete spots (right-lower panel).

polyploid cells, apoptotic cell death and survival of a considerable amount of cells) allow us to consider that $\mathrm{ZnPc}$ photosensitization of HeLa cells induced the mitotic catastrophe.

\section{Discussion}

Cell death triggering is the main objective of oncological therapy. Several chemotherapeutical drugs have been developed in the last decades with different success rates (28). The knowledge about the action of the anti-tumour agents has increased and several cell death mechanisms have been proposed (8). The Nomenclature Committee on Cell Death reviewed them in 2005 to clarify the concepts, promoting three main processes: apoptosis (type 1), autophagy (type 2) and necrosis (type 3), and also admitting the presence of other particular phenomena in specific models (8).

Mitotic catastrophe is one of these particular phenomena and, until present, it lacks an adequate definition; it is often 
described simply as a cell death resulting of aberrant mitosis $(29,30)$. Mitotic catastrophe is often related closely with sublethal conditions of different treatments that triggers a delayed cell death response $(12,31)$. It has been contradictorily linked with both apoptotic and non-apoptotic processes (29). The molecular mechanisms that lead to morphological features used to describe the mitotic catastrophe (metaphase blockage, interphase restitution, aneuploidy and cell death) are not clearly understood $(7,32)$. Several studies indicate that the abrogation of functional p53 is required for this response to treatments $(12,33,34)$ but, depending on the model or the timing of the process, the activation of some p53-regulated genetic pathways is also important $(9,11,12)$.

PDT constitutes an appropriate tool for studying cell death mechanisms as the injury intensity is easily monitored (22). Although it was early considered that necrosis was the main cell death process induced by PDT (35), now it is well known that PDT treatments induce apoptosis $(22,36)$. There are published studies connecting PDT and autophagy, as a consequence of apoptosis inhibition or as the main cell death mechanism $(35,37)$. Hovewer, the precise mechanism of cell death in PDT treatments remains elusive due to the variability of the conditions employed.

Upon appropriate light irradiation, PSs act in the cell as sources of ROS generated by the photochemical reaction type II (1), which cause important macromolecular damage to regions where they are produced and in its proximity (22). However, ROS can also act as messengers triggering different signalization pathways either leading to death (by $\mathrm{Ca}^{2+}$ release) or resistance (stimulating different kinases) responses (22). The molecular cascades concerned in the cell death triggering are complex, and often different mechanisms share the same pathway (38).

$\mathrm{ZnPc}$ is one of the most promising PDT agents due to the diversity of their delivery systems $(3,5,39)$. As other PSs, $\mathrm{ZnPc}$ induces different death responses on cell cultures, examples being the classical necrosis and apoptosis $(23,40)$ and other mechanisms like detachment-linked cell death (anoikis) (41). Recently, Alexadratou and co-workers have revealed, using confocal microscopy, the events activated in the very first minutes after non-lethal ZnPc-PDT treatment of human foetal foreskin fibroblasts HFF2 cells at a single-cell scale. They verify transitory increased ROS levels, which lead to transient acidification, loss of the mitochondria membrane potential and $\mathrm{pH}$ gradients, and $\mathrm{Ca}^{2+}$ influx (4).

On account of the reduced life time of ROS, the specific subcellular localisation of PSs will be the most damaged site of the cell (39). In the case of $\mathrm{ZnPc}$, the precise subcellular accumulation site seems to be dependent on the cell line (as occurs with other PSs). Fabris and co-workers have proposed a localisation of $\mathrm{ZnPc}$ in the Golgi apparatus of $4 \mathrm{R}$ rat fibroblasts (40). This result was consequent with previous observations in NHIK 3025 cells (39) showing a rapid damage both in Golgi apparatus and mitochondria. On the other hand, more recent data using a computer algorithm to analyse confocal microphotographs, indicated a mitochondrial localisation of $\mathrm{ZnPc}$ in human HFFF2 cells (4). Besides, there is also evidence, using hydrosoluble derivatives of $\mathrm{ZnPc}$, of PS re-localisation (from plasma membrane to Golgi and cell nucleus) after light irradiation (42).
In the present work, we observed that in HeLa cells $\mathrm{ZnPc}$ accumulated within a single wide area near the nucleus that did not correspond to mitochondria. By comparison with organelle specific markers (golgin 58 and cytochrome c), the accumulation site of $\mathrm{ZnPc}$ strongly resembles to the pattern of the Golgi apparatus in this cell line (see Fig. 1).

Our results show that the uptake of ZnPc-DPPC by HeLa cells depends of both concentration and incubation time, in agreement with previous reports $(39,40,43)$. We found no references similar to our experimental conditions (very short incubation with low doses of $\mathrm{ZnPc}$ ) as uptake studies were usually performed at higher concentrations and increased time intervals. Despite this, our results using the longest incubation time with the highest concentration (24-h incubation with $2.5 \mu \mathrm{M} \mathrm{ZnPc}$, see Table I) are within the magnitude order showed previously by Valduga and co-workers in $4 \mathrm{R}$ transformed fibroblasts (43) and indicate that the uptake kinetics in HeLa cells may not differ greatly from other models.

Previously we have described that in HeLa cells both apoptosis and necrosis, as well as characteristic cytoskeleton alterations and accumulation of mitotic cells with abnormal spindles were produced by $\mathrm{ZnPc}(23,24)$. Photodamage to microtubules was also described either with $\mathrm{ZnPc}$ or other PSs $(24,36,39)$. The tubulin photodamage resulted from the disappearance of tubulin in soluble protein fractions after lethal treatments, but no diminution was observed in sublethal treatments inducing altered mitotic cells which show the typical morphology of the mitotic catastrophe (24).

The origin of the alterations of the mitotic spindle, mainly the appearance of supernumerary poles is far from completely understood, but deficiencies in p53 signalling seem to be related with this process (44). As mentioned above, there is a broad consensus on the fact that p53 abrogation allows the cells to survive after mitotic slippage and appearance of aneuploidy (12). In this sense, it is important to remark that HeLa cells constitutes one of the best known models of cell lines that lack functional p53 protein due to the activity of the host HPV16 viruses (25). There are very few reports about the relationship between p53, cell cycle blockage and sensitivity to PDT treatments. The results seem to be confusing as they are highly dependent on the cell model employed. Thus Photofrin ${ }^{\circledR}$-mediated cell photokilling can occur either without correlation with p53 abrogation in colon cancer cells (45) or with p53 dependency in Li-Fraumeni syndrome cells (46). In this example it is important to note that p53 absence was positively linked with resistance development through $\mathrm{G}_{2} / \mathrm{M}$ blockage and delayed apoptosis (46). More recently, Lee and co-workers stated that the p53 status does not interfere at all, in terms of survival rates, in the response of U2OS osteosarcoma cells to hypericin (47).

Herein we have shown that $\mathrm{ZnPc}$ induced metaphase blockage of HeLa cells followed by apoptotic death of the arrested cells. Six hours after treatment, about $29.5 \%$ of cells were either blocked in metaphase or became aneuploid (Fig. 2). The metaphase blockage was clearly correlated with the presence of abnormal mitotic spindles, mainly by the presence of supernumerary poles (Fig. 3). At $24 \mathrm{~h}$ after the treatment, cells started to detach from surface, and $72 \mathrm{~h}$ later, cell counting revealed $35.7 \%$ of apoptosis, these values 
corresponding with those from MTT and TB survival assays (Table II). At this time some mitotic cells were observed, although the mitotic index was reduced to $3.11 \%$. Death cells showed morphological features (rounding, shrinkage, chromatin condensation and fragmentation) that are typical of apoptotic cells. We also confirmed apoptosis as the cell death mechanism by PARP cleavage and Bax translocation (from cytosol to mitochondria) in dying cells (Fig. 4). To our knowledge, this is the first reference of Bax translocation to mitochondria supported by immunolabelling images using $\mathrm{ZnPc}$, and confirms previous data obtained with other PSs and chemotherapeutic agents $(48,49)$. Bax translocation must be not considered strictly p53-dependent as there are also observations describing it, in mitotic catastrophe, as a process partially independent of p53 $(9,12)$.

In conclusion, our results indicate that after ZnPc-PDT apoptotic HeLa cells were first blocked in metaphase and some of those evolved to aneuploid ones. Metaphase blockage, aneuploidy and delayed apoptosis are the main features of mitotic catastrophe. PDT can cause cell death by mitotic catastrophe under sublethal conditions. Obviously, further research is needed to clarify the biochemical processes underlying this morphological process. As mitotic catastrophe is observed normally in sublethal or delayed-lethality conditions, it is often considered as an 'open gate' to resistance and survival by means of aneuploidy-linked genomic instability (normally caused by p53 deficiency) $(31,50)$. In this sense, we consider that mitotic catastrophe requires more attention in cancer research because it can be really useful to better characterise the action mechanism of chemotherapeutic drugs.

\section{Acknowledgements}

The authors recognise the valuable contribution of Sylvia Gutierrez (Confocal Microscopy and Flow Cytometry Service, Centro Nacional de Biotecnología, Madrid) and Dolores Morales (Confocal Microscopy Laboratory, Interdepartmental Research Service, Universidad Autónoma de Madrid). This work was supported by grants from Comunidad Autónoma de Madrid (S-0505 MAT-0194) and Ministerio de Educación y Ciencia (CTQ2007-67763-C03-02/BQU), Spain.

\section{References}

1. Triesscheijn M, Baas P, Schellens JHM and Stewart FA: Photodynamic therapy in oncology. Oncologist 11: 1034-1044, 2006.

2. Konan YN, Gurny R and Allémann E: State of the art in the delivery of photosensitizers for photodynamic therapy. J Photochem Photobiol B Biol 66: 89-106, 2002.

3. Ricci-Júnior E and Marchetti JM: Zinc(II)phthalocyanine loaded PLGA nanoparticles for photodynamic therapy use. Int J Pharmaceut 310: 187-195, 2006.

4. Alexandratou E, Yova D and Loukas S: A confocal microscopy study of the very early cellular response to oxidative stress induced by zinc phthalocyanine sensitization. Free Radic Biol Med 39: 1119-1127, 2005.

5. Sibata MN, Tedesco AC and Marchetti JM: Photophysicals and photochemicals studies of zinc(II) phthalocyanine in long time circulation micelles for photodynamic therapy use. Eur J Pharmaceut Sci 23: 131-138, 2004.

6. Nunes SMT, Sguilla FS and Tedesco AC: Photophysical studies of zinc phthalocyanine and chloroaluminum phthalocyanine incorporated into liposomes in the presence of additives. Braz J Med Biol Res 37: 273-284, 2004.
7. Galluzzi L, Maiuri MC, Vitale I, Zischka H, Castedo M, Zitvogel L and Kroemer G: Cell death modalities: classification and pathophysiological implications. Cell Death Differ 14: $1237-1266,2007$

8. Kroemer G, El-Deiry WS, Golstein P, et al: Classification of cell death: recommendations of the Nomenclature Commitee on Cell Death. Cell Death Differ 12: 1463-1467, 2005.

9. Castedo M, Coquelle A, Vivet S, et al: Apoptosis regulation in tetraploid cancer cells. EMBO J 25: 2584-2595, 2006.

10. Baker DJ, Chen J and van Deursen JMA: The mitotic checkpoint in cancer and aging: what have mice taught us? Curr Opin Cell Biol 17: 583-589, 2005

11. Chen JG, Yang CPH, Cammer M and Horwitz SB: Gene expression and mitotic exit induced by microtubule stabilizing drugs. Cancer Res 63: 7891-7899, 2003.

12. Castedo M, Perfettini JL, Roumier T, Andreau K, Medema R and Kroemer G: Cell death by mitotic catastrophe: a molecular definition. Oncogene 23: 2825-2837, 2004.

13. Kastan MB and Bartek J: Cell-cycle checkpoints and cancer. Nature 432: 316-323, 2004

14. Rello-Varona S, Gámez A, Moreno V, et al: Metaphase arrest and cell death induced by etoposide on HeLa cells. Int J Biochem Cell Biol 38: 2183-2195, 2006.

15. Jordan MA, Wendell K, Gardiner S, Derry WB, Copp H and Wilson L: Mitotic block induced in HeLa cells by low concentrations of paclitaxel (taxol) results in abnormal mitotic exit and apoptotic cell death. Cancer Res 56: 816-825, 1996.

16. Jordan MA and Wilson L: Microtubules as a target for anticancer drugs. Nat Rev Cancer 4: 253-265, 2004.

17. Jackson JR, Patrick DR, Dar MM and Huang PS: Targeted antimitotic therapies: can we improve on tubulin agents? Nat Rev Cancer 7: 107-117, 2007.

18. Ferri KF and Kroemer G: Organelle-specific initiation of cell death pathways. Nat Cell Biol 3: E255-E263, 2001.

19. Kim H, Rafiuddin-Shah M, Tu HC, Jeffers JR, Zambetti GP, Hsieh JJD and Cheng EHY: Hierarchical regulation of mitochondrion-dependent apoptosis by BCL-2 subfamilies. Nat Cell Biol 8: 1348-1358, 2006.

20. Van Delft MF and Huang DCS: How the Bcl-2 family of proteins interact to regulate apoptosis. Cell Res 16: 203-213, 2006.

21. Srivastava M, Ahmad N, Gupta S and Mukhtar H: Involvement of Bcl-2 and Bax in photodynamic therapy-mediated apoptosis. J Biol Chem 276: 15481-15488, 2001.

22. Almeida RD, Manadas BJ, Carvalho AP and Duarte CB: Intracellular signaling mechanisms in photodynamic therapy Biochim Biophys Acta 1704: 59-86, 2004.

23. Villanueva A, Domínguez V, Polo S, et al: Photokilling mechanisms induced by zinc(II)-phthalocyanine on cultured tumor cells. Oncol Res 11: 447-453, 1999

24. Juarranz A, Espada J, Stockert JC, Villanueva A, Polo S, Domínguez V and Cañete M: Photodamage induced by zinc(II)-phthalocyanine to microtubules, actin, alpha-actinin and keratin of HeLa cells. Photochem Photobiol 73: 283-289, 2001.

25. May E, Jenkins JR and May P: Endogenous HeLa p53 proteins are easily detected in HeLa cells transfected with mouse deletion mutant p53 gene. Oncogene 6: 1363-1365, 1991.

26. Ginevra F, Biffanti S, Pagnan A, Biolo R, Reddi E and Jori G: Delivery of the tumour photosensitizer zinc(II)-phthalocyanine to serum proteins by different liposomes: studies in vitro and in vivo. Cancer Lett 49: 59-65, 1990.

27. Rello S, Stockert JC, Moreno V, et al: Morphological criteria to distinguish cell death induced by apoptotic and necrotic treatments. Apoptosis 10: 201-208, 2005

28. Varmus H: The new era in cancer research. Science 312: $1162-1165,2006$.

29. Stevens JB, Liu G, Bremer SW, et al: Mitotic cell death by chromosome fragmentation. Cancer Res 67: 7686-7694, 2007.

30. Mansilla S, Priebe W and Portugal J: Mitotic catastrophe results in cell death by caspase-dependent and caspase-independent mechanisms. Cell Cycle 5: 53-60, 2006.

31. Erenpreisa JE and Cragg MS: Mitotic death: a mechanism of survival? A review. Cancer Cell Int 1: 1, 2001.

32. Blagosklonny MV: Mitotic arrest and cell fate. Cell Cycle 6: 70-74, 2007.

33. Pantic M, Zimmermann S, El Daly H, Opitz OG, Popp S, Boukamp P and Martens UM: Telomere dysfunction and loss of p53 cooperate in defective mitotic segregation of chromosomes in cancer cells. Oncogene 25: 4413-4420, 2006. 
34. Andreassen PR, Lacroix FB, Lohez OD and Margolis RL: Neither $\mathrm{p} 21^{\mathrm{WAF} 1}$ nor $14-3-3 \sigma$ prevents $\mathrm{G}_{2}$ progression to mitotic catastrophe in human colon carcinoma cells after DNA damage, but $\mathrm{p} 21^{\mathrm{WAF} 1}$ induces stable $\mathrm{G}_{1}$ arrest in resulting tetraploid cells. Cancer Res 61: 7660-7668, 2001.

35. Kessel D, Vicente MGH and Reiners JJ: Initiation of apoptosis and autophagy by photodynamic therapy. Autophagy 2: 289-290, 2006.

36. Villanueva A, Vidania R, Stockert JC, Cañete M and Juarranz A: Photodynamic effects on cultured tumor cells. Cytoskeleton alterations and cell death mechanisms. In: Handbook of Photochemistry and Photobiology. Vol. 4. Nalwa HS (ed.) American Scientific Publishers, Los Angeles, pp79-117, 2003.

37. Buytaert E, Callewaert G, Hendrickx N, et al: Role of endoplasmic reticulum depletion and multidomain proapoptotic BAX and BAK proteins in shaping cell death after hypericinmediated photodynamic therapy. FASEB J 20: 756-758, 2006.

38. Danial NN and Korsmeyer SJ: Cell death: critical control points. Cell 116: 205-219,2004.

39. Rodal GH, Rodal SK, Moan J and Berg K: Liposome-bound $\mathrm{Zn}$ (II)-phthalocyanine. Mechanisms for celular uptake and photosensitization. J Photochem Photobiol B Biol 45: 150-159, 1998.

40. Fabris C, Valduga G, Miotto G, Borsetto L, Jori G, Garbisa S and Reddi E: Photosensitization with zinc (II) phthalocyanine as a switch in the decision between apoptosis and necrosis. Cancer Res 61: 7495-7500, 2001.

41. Galaz S, Espada J, Stockert JC, et al: Loss of E-cadherin mediated cell-cell adhesion as an early trigger of apoptosis induced by photodynamic treatment. J Cell Physiol 205: 86-96, 2005.

42. Wood SR, Holroyd JA and Brown SB: The subcellular localization of $\mathrm{Zn}$ (II) phthalocyanines and their redistribution on exposure to light. Photochem Photobiol 65: 397-402, 1997.
43. Valduga G, Bianco G, Csik G, Reddi E, Masiero L, Garbisa S and Jori G: Interaction of hydro- or lipophilic phthalocyanines with cells of different metastatic potential. Biochem Phamacol 51: 585-590, 1996.

44. Tsou MFB and Stearns T: Controlling centrosome number: licenses and blocks. Curr Opin Cell Biol 18: 74-78, 2006.

45. Fisher AMR, Ferrario A, Rucker N, Zhang S and Gomer CJ: Photodynamic therapy sensitivity is not altered in human tumor cells after abrogation of p53 function. Cancer Res 59: 331-335, 1999.

46. Tong Z, Singh G and Rainbow AJ: The role of the p53 tumor suppressor in the response of human cells to Photofrin-mediated photodynamic therapy. Photochem Photobiol 71: 201-210, 2000 .

47. Lee HB, Ho ASH and Teo SH: p53 status does not affect photodynamic cell killing induced by hypericin. Cancer Chemother Pharmacol 58: 91-98, 2006.

48. Sarkar FH, Rahman KMW and Li Y: Bax translocation to mitochondria is an important event in inducing apoptotic cell death by Indole-3-carbinol (I3C) treatment of breast cancer cells. J Nutr 133: S2434-S2439, 2003.

49. Chiu SM, Xue LY, Usuda J, Azizuddin K and Oleinick NL: Bax is essential for mitochondrion-mediated apoptosis but not for cell death caused by photodynamic therapy. Br J Cancer 89: 1590-1597, 2003

50. Merlo LMF, Pepper JW, Reid BJ and Maley CC: Cancer as an evolutionary and ecological process. Nat Rev Cancer 6: 924935, 2006. 